\title{
Balance of Interests \\ in Protecting the Children's Rights: \\ Legal Positions of the ECtHR \\ and National Courts
}

\author{
Kristina V. Pylina* \\ Siberian Federal University \\ 79 Svobodny, Krasnoyarsk, 660041, Russia
}

Received 22.05.2017, received in revised form 07.06.2017, accepted 12.06.2017

The author claims that children are recognized as independent subjects requiring special attention and protection. Their rights and interests are guaranteed by both national and international legislation. The authorities' interference in the family relations should pursue a legitimate aim with the means of interference being correspondent to this legitimate aim. The author recommends that in solving disputes involving children it is necessary to search for an equitable balance of interests, which is multi-vector. The balance assumes consideration of interests of all participants of family relations. The children's interests are independent and do not depend on their parents' interests. In some cases, the children's interests can even prevail over the parents' interests. The application of the European Court judgments, which offers balancing interfering interests, will reduce the number of violations of children's rights and ensure their observance.

Keywords: balance of interests, children's interests, European Convention, European Court of Human Rights, family relationship, state interference.

DOI: 10.17516/1997-1370-0098.

Research area: law.

\section{Introduction}

Every year, the European Court of Human Rights (hereinafter referred to as the European Court or ECtHR) receives complaints about violations of Article 8 of the Convention for the Protection of Human Rights and Fundamental Freedoms, which guarantees the right to respect for private and family life. The European Court regularly records violations of the children's and parents' rights by state bodies. According to official data on the European Court of
Human Rights website, in 2014, there were found 13 violations of Article 8 of the European Convention (Violations, 2014) by state bodies of the Russian Federation. In 2015, the number of violations decreased to 6 (Violations, 2015). However, in 2016, the figure returned to their previous level 12 (Violations, 2016). Unfortunately, the negative trend as regards violation of Article 8 of the European Convention by the national authorities of the Russian Federation persists.

(C) Siberian Federal University. All rights reserved

* Corresponding author E-mail address: kristinkasmile@mail.ru 
Despite the small number of violations of Article 8 of the European Convention the children's rights should represent specially protected by the state area, so even single violations are unacceptable. Violation of the right to respect for family life can entail serious consequences: the family separation (Saviny v. Ukraine, 2008; Olsson v. Sweden, 1988), children not receiving information about their origin (Godelli v. Italy, 2012), actual obstacles to family creation (Costa and Pavan v. Italy, 2012) or to family existence (K. Markin v. Russian Federation, 2012; Marckx v. Belgium, 1979). Such violations contravene international standards, and as a result violate the international obligations of the Russian Federation.

\section{Statement of the problem}

Family relations belong to the private sphere so many relative issues are not regulated by the state. At the same time, the right to respect for family life is not absolute. The state has the right to intervene in the exercise of this right. However, such interference must pursue a legitimate aim: in the interests of national security and public order, the economic well-being of the country, for the prevention of disorder or crime, for the protection of health or morals, or for the protection of the rights and freedoms of others (Part 2, Article 8 of the European Convention). Pursuing a legitimate aim, employees of migration services, other state bodies, as well as judges often neglect the interests of participants in family relations. And then the dispute is referred to the European Court of Human Rights if all internal avenues have been exhausted. The mechanism of national control is therefore complemented by an international mechanism.

As for violation of Article 8 of the European Convention, the European Court checks whether there has been a balance of interests in cases of state interference. National courts are not always able to achieve a balance, because states are guided primarily by the provisions of national legislation, and do not analyze whether the interference was necessary in a democratic society and whether there was a balance of interests (Tereshkova, 2007).

In some cases finding a balance is not easy. In our opinion, in order to achieve a balance, it is necessary to take into account the extent to which the means for achieving a legitimate goal are correspondent to state intervention. In addition, this balance is multi-vector. The European Court's detection of violations of Art. 8 of the European Convention entails reforming national legislation along with the modification of national jurisprudence.

The significance of the European Court's decisions for the legal system of the Russian Federation is actively discussed in the doctrine (Marchenko, 2006; Tereshkova, 2011; Zimnenko, 2010). I share the position that taking into consideration the decisions of the European Court should not be regarded as a violation of the state sovereignty of the Russian Federation (Soboleva, 2012). Recognition of the priority of norms and principles of international law results not from a decision on a particular case, but from Part 4 of Art. 15 of the RF Constitution, which once directly proclaimed that the principles and norms of international law are a constituent part in the Russian Federation legal system.

\section{Methods}

As for the main methods of research, the author used methods of analysis, synthesis and comparison, analyzing how the balance is sought by the European Court and the national courts of the Russian Federation. The empirical basis of the study includes the decisions of the European Court of Human Rights and of the national courts of the Russian Federation on family matters, as well as Rulings of the highest federal judicial bodies. 


\section{Discussion}

The search for a fair balance is the most effective way to resolve disputes in which the rights of children are affected. The European Court of Human Rights has repeatedly examined the issue of balancing children's and parents' interests, children's and state's interests. However, the criteria for determining the balance have not yet been determined precisely. The most reasonable definition seems to be one which sees the balance of interests as the state of the legal relationship in which the parties' rights and obligations are proportionate, and the parties have equal opportunities to realize their legitimate interests (P'iankova, 2016).

It is worth mentioning that the search for such a balance requires a broad analysis of the circumstances in each case. The law enforcer must answer the following questions, whether the intervention of the state is allowed by law, whether it is aimed at achieving a legitimate goal and whether such intervention is necessary to achieve a legitimate aim (Tereshkova, 2007).

The notion of necessity implies that the intervention corresponds to an urgent social need and that it is commensurate with the legitimate aim pursued (Olsson v. Sweden, 1988: § 67). In most cases, the intervening state pursues legitimate aim, but not always the intervention is necessary in a democratic society.

\section{The balance between private \\ and public interests}

In any society, the rights of one person end there and then, where the rights of another person begin. The rights of each individual should be harmoniously combined with the interests of other individual members of society, which is necessary for setting a balance between the rights of an individual and the state interests.

The state forms legislation, the provisions of which in some cases may violate the rights of family members. For example, in the case of Shofman v. Russia (2005), the applicant requested to be struck off as a father from a child's birth certificate. Being married to a Russian citizen, the applicant moved to Germany and was waiting for his wife and his son to move to Germany. Later, however, the spouse notified the applicant that she intended to dissolve the marriage and file an action with the court for the child maintenance. Simultaneously, the applicant's relatives informed him that he was not the biological father of the child. The applicant filed a divorce petition and a claim for challenging paternity. The national court found that the applicant, according to the results of DNA tests, was not the child's father, but the application for challenging paternity was refused in view of the expiry of the statute of limitations. The Code of the RSFSR on Marriage and Family, applicable in this case, since the child was born before March 1, 1996 (the date when the new Family Code of the Russian Federation came into force), established a period of one year to challenge paternity, this period to be calculated from the moment when the person was notified of the paternity registration. The European Court found that the applicant did not challenge paternity immediately after the child's birth (12 May 1995), and applied to the court only in December 1997. Thus, the applicant missed the limitation period to challenge paternity as established by the Russian Federation legislation. The applicant claimed that the state violated his right to family life, since the family law provides for the commencement of the limitation period for paternity challenging from the moment when he is notified or should have become aware of such a record. The European Court found that there had been a violation of Art. 8 of the Convention for the Protection of Human Rights and Fundamental Freedoms. The European Court emphasized that the Russian Federation authorities did not indicate the reasons why it was 
necessary in a democratic society to establish a strict deadline that begins regardless of whether the alleged father knows about challenging his paternity circumstances and why the law does not provide for any exceptions from this period definition (§ 43).

A similar situation has arisen in the case of Mizzi v. Malta (2006). The applicant complained that it was impossible to challenge the presumption of his paternity, which was applied in his case. Besides, he asserted that he was discriminated, because these stringent requirements and periods of limitation did not apply to other parties interested in paternity investigation. There has been a violation of Article 8 of the ECHR. In the Court's view, the fact that the applicant could not at any time contest his paternity was not relevant as regards the legitimate aim pursued.

In both cases (Shofman v. Russia, 2005; Mizzi v. Malta, 2006), the national courts did not observe a fair balance between public interest, which is to protect the principle of legal certainty of family relations, and the applicant's right to have the legal presumption of his fatherhood examined in a court in the light of biological evidence.

In such a situation, when the norms of the current national legislation do not comply with modern international standards, the law enforcer should be guided by the norms of international law, as well as by the current positions of the European Court of Human Rights. It should be noted that in the case of Shofman v. Russia, there could be applied the new Family Code of the Russian Federation, the norms of which have changed in comparison with the RSFSR Code on Marriage and Family and which has ruled out the statute of limitations in the case of challenging paternity.

Family disputes inevitably involve several participants. There are frequent cases where not only private and public interests contradict, but also the private interests of the participants.

\section{Balance between the parents' interests}

Particular attention should be drawn to the situation when it is necessary to achieve a balance between the parents' interests. Seeking a fair balance in such cases, the European Court reckons a wide range of circumstances. Whether these or those circumstances are important is determined separately for each case. The current practice of the European Court has shown that these circumstances are: the type of professional activity, state of health, religious views, many other circumstances that, at first glance, do not per se belong to family relations.

In the case of Hoffmann v. Austria (1993), the applicant belonged to the Roman Catholic Church, she married a man of the same religion, together they baptized children and brought them up in the same faith. However, later she converted to the church of Jehovah's Witnesses and divorced her husband, taking the children to live with her. The Austrian Supreme Court considered that the mother's religion would have a negative impact on children, making allowance for a negative attitude towards blood transfusions, surgical interventions and public holidays. The ECtHR considered the decision of the Supreme Court of Austria incompatible with the Convention, since it amounts to discrimination against one of the parents on the religious basis. Although the ECtHR did not deny that certain social factors pertaining to membership in the Jehovah's Witnesses sect can tip the balance in favor of one parent in the matter of custody, it supported the view that any distinction between parents based essentially on the religious difference is unacceptable.

In another case, the court took the opposite decision. Under similar circumstances, in the case of Ismailova v. Russia (2007) the mother was a member of the Jehovah's Witnesses sect, and the national courts of the Russian Federation left the children with their father. The European Court agreed that the Russian national courts 
reached a balance and confirmed the absence of violations of Article 8 of the Convention, as the mother's actions related to her participation in the sect activities had an obviously adverse effect on the children (the case file had the conclusion of a psychological examination).

In the above cases, to determine the fair balance the criterion of the children's best interests was on the foreground. This factor was decisive when leaving the child with one of the parents. It is important to understand that in the confrontation of the parents' interests, not only their interests should be taken into account; they must be combined with the child's interests. Therefore, all arguments presented by the parties should be considered in the context of ensuring the child's best interests.

\section{Balance between the parents \\ and children's interests}

Some competition can arise between the parents' and the child's interests. Unfortunately, parents do not always keep the child's interests in mind. Sometimes this is due to a lack of interest on their part, in other cases, parents may be overwhelmed by their own problems or generally overburdened by the current situation (Maywald, 2016). In such cases, it is also crucial to maintain a fair balance.

The duty of parents is the realization of the child's rights and interests. Meanwhile, parents and children are equal and independent subjects of rights, which means that each has independent interests, which in some cases may be opposite.

The absence of a legal mechanism for balancing the child's rights to know his or her origin with the mother's rights to and interests in preserving anonymity may lead to a violation of the right guaranteed by Art. 8 of the European Convention.

The case of Godelli v. Italy (2012) concerned the confidentiality of information about the child's birth and the impossibility for this unwanted child to learn about her origin. The European Court held that there had been a violation of Article 8, since the Italian legal system does not take into account the child's interests. The court concluded that there was no balance between the interests of different parties, as the legislation governing the mother's refusal to disclose information about herself did not provide for the opportunity for a child, from whom the mother had refused at birth and who was subsequently adopted by another family, to request information about her origin without revealing the mother's identity.

\section{The child's interests}

More than once the European Court has stressed the special importance of the child's highest interests, which, depending on their nature, can prevail over the parents' interests.

And although this priority is not absolute, all other problems and interests should be weighed and correlated with the child's interests. Every time, while determining what is best for a child in a particular case, it is necessary to taking into account the circumstances. All factors that affect the welfare and development of the child should be taken into consideration, including the following: age, maturity, gender, physical and mental condition, family, social, financial situation, linguistic knowledge. If, in making a decision, the national authorities ignore or disdain the child's interests, the decision will not comply with the provisions of international standards that protect the children's rights (Cremer, 2012).

For example, in the case of Olsson v. Sweden (1988), despite the parents' efforts to leave children, three children were placed under guardianship. The social authorities felt that their development was at risk for various reasons, including the parents' inability to satisfy their emotional and intellectual needs. In particular, it was found that children noticeably lagged behind 
in intellectual development and in mastering speech. It should be noted that the applicants themselves also had moderate mental abilities. Probably, that is why they could not provide the children with the necessary conditions for development. However, the decisive reason for the state's compulsory intervention was not the alleged mental retardation of parents, but their inability to provide children with a satisfactory level of care and upbringing.

On the state's part, various measures have been taken to help the family; several social welfare institutions, independently of each other, have been involved in the affairs of the Olsson family. National authorities approached this issue with particular attention: the decision to withdraw children was based on a detailed report prepared by the social services after the children had been taken under temporary supervision to examine their situation. The conclusions of this report were confirmed by the statements of a number of persons well acquainted with the circumstances of the case in question, including also a doctor and a psychologist.

In the light of the above mentioned facts, the ECtHR concluded that the impugned decision was supported by sufficient grounds and that, given the legal framework, the Swedish authorities had reasonable grounds to believe that it was necessary to take the children into custody, inasmuch as the preliminary measures had been ineffective (Olsson v. Sweden, 1988: § 74). Despite the fact that the authorities' actions to separate the children from their parents were correct, the European Court considered that placing children in various families violated their right to communicate, guaranteed by Art. 8 ECHR. Thus, the national authorities, acting within the framework of legitimate aims, could not ensure the children's best interests.

Another decision in the Chepelev v. Russia case (2007) is of interest in connection with the
European Court's decision not to recognize the moot case as the violation of the Convention. Chepelev, being a biological father, objected to the adoption of his daughter by his ex-wife's new husband, since this violated his right to respect for family life. However, the applicant did not fulfill his parental responsibilities. The European Court concluded that the state's interference was carried out in accordance with the law and pursued the legitimate aim of protecting the child's interests. The European Court pointed out that before the adoption, the contacts between the applicant and his daughter were rare and limited, before the adoption he had hardly seen her for more than three years. The person who acted as an adoptive parent married the applicant's ex-wife and by the time the child was adopted had lived together with the woman and the child for three years, so she took him as her father, therefore de facto this man and the applicant's daughter had truly family relations. The European Court acknowledged that the adoption consolidated the actual relations, that is why it was possible to adopt the child without the consent of the father living apart from the child, who barely had any contacts with her biological father.

\section{Conclusion}

Article 8 of the European Convention on the Protection of Human Rights and Fundamental Freedoms imposes on the national authorities the obligations to ensure a balance of interests of all participants in family relations.

The greatest significance is the child's interests, which in some cases may have priority over the interests of the parents.

In our opinion, the search for a balance of interests is an effective means and, perhaps, the only possible way of making decisions on complaints about violations of the right to respect for family life. Finding such a balance is weighing of the respective benefits and interests on the basis of the specific circumstances in each case. 
Relying on the analysis of the practice of the European Court of Human Rights, the national courts must pay due consideration to the following circumstances:

- Intervening in the sphere of family relations, national authorities should not only follow a legitimate aim, but also try to find correspondent to this goal means.

- The balance of interests is multi-vector, that is, when it is sought, law enforcement should address the interests of all participants in family legal relations.

- Using only national legislation in making decisions can lead to the disbalance, as its provisions do not always correspond to modern standards.

- When resolving disputes affecting family relations, the widest possible list of circumstances relevant to the case should be taken into account.

- The protection of the right to respect for family life is not allowed when any of the participants in the family relationship is discriminated.

- Parents and children are equal and independent subjects of rights, which means that each has an independent interest that may not coincide.

- Depending on their nature, the children's interests can prevail over the parents' interests.

The use of the ECtHR legal positions does not deprive the national courts of their selfsustainability and independence in decisionmaking, at the same time it guarantees the observance and enforcement of the child's rights, as well as the fulfillment of the state's international obligations.

\section{References}

Cremer, H. (2012). Children's rights and the primacy of childhood. The UN-Convention on the Rights of the Child offers a wide field of application [Kinderrechte und der Vorrang des Kindeswohls. Die UN-Kinderrechts convention bietet ein weites Anwendungsfeld], In AnwBl, 4, 327-329.

European Convention on Human Rights (ECHR). (1950). (Formally the Convention for the Protection of Human Rights and Fundamental Freedoms), Rome.

European Court of Human Rights. Appl. No. 10465/83, Olsson v. Sweden, (1988).

European Court of Human Rights. Appl. No. 12875/87, Hoffmann v. Austria, (1993).

European Court of Human Rights. Appl. No. 26111/02, Mizzi v Malta, (2006).

European Court of Human Rights. Appl. No. 30078/06, K. Markin v. Russian Federation, (2012).

European Court of Human Rights. Appl. No. 33783/09, Godelli v. Italy, (2012).

European Court of Human Rights. Appl. No. 37614/02, Ismailova v. Russia, (2007).

European Court of Human Rights. Appl. No. 39948/06, Saviny v. Ukraine, (2008).

European Court of Human Rights. Appl. No. 54270/10, Costa and Pavan v. Italy, (2012).

European Court of Human Rights. Appl. No. 58077/00, Chepelev v. Russia, (2007).

European Court of Human Rights. Appl. No. 6833/74, Marckx v. Belgium, (1979).

European Court of Human Rights. Appl. No. 74826/01, Shofman v. Russia, (2005).

Marchenko, M.N. (2006). Iuridicheskaia priroda i kharakter reshenii Evropeiskogo Suda po pravam cheloveka [The legal nature and character of the European Court of Human Rights decisions], In Gosudarstvo i pravo [State and Law], 2,11-19.

Maywald, J. (2016). Rights of the child, parents' rights, and state monitoring. When is state intervention in parental autonomy permissible? [Kinderrechte, Elternrechte und staatliches 
Wächteramt. Wann darf der Staat in die elterliche Autonomie eingreifen?], In Bundesgesundheitsbl, 59: 1337-1342. DOI: 10.1007/s00103-016-2429-1.

P'iankova, A.F. (2016). Printsip balansa interesov v praktike Evropeiskogo Suda po pravam cheloveka [The principle of the balance of interests in the European Court of Human Rights], In Evraziiskaia advokatura [Eurasian Advocacy], 4 (23), available at: http://www.eurasian-advocacy. $\mathrm{ru} /$ prava-cheloveka-v-evrazijskom-prostranstve/1846-printsip-balansa-interesov-v-praktikeevropejskogo-suda-po-pravam-cheloveka.

Soboleva, A.K. (2012). ESPCH $i$ Konstititsionnii sud RF: Konflikt tolkovanii [ECHR and the Constitutional Court of the Russian Federation: Conflict of interpretations]. Available at: www. igzakon.ru/magazine/article-pdf/?id=3812.

Tereshkova, V.V. (2007). Primenenie mezhdunarodnykh norm o zashchite prav cheloveka natsional'nymi sudebnymi organami [Application of international norms on the protection of human rights by national judicial authorities], In Sovremennoe sostoianie teorii, zakonodatel'stva i praktiki konstitutsionnogo prava zarubezhnykh stran [The current state of the theory, legislation and practice of constitutional law of foreign countries], 215-222.

Tereshkova, V.V. (2011). Neposredstvennoe deistvie postanovlenii ESPCH v natsional'noi pravovoi sisteme [The direct effect of the ECHR judgments in the national legal system], In Sbornik statei "Vserossiiskaia nauchno-prakticheskaia konferentsiia "Pravovye problemy ukrepleniia rossiiskoi gosudarstvennosti" [Proceedings of all-Russian scientific-practical conference "Legal problems of Strengthening Russian Statehood"']. Tomsk.

Violations by Article and by State. (2014). Available at: http://www.echr.coe.int/Documents/ Stats_violation_2014_ENG.pdf.

Violations by Article and by State. (2015). Available at: http://echr.coe.int/Documents/Stats violation_2015_ENG.pdf.

Violations by Article and by State. (2016). Available at: http://echr.coe.int/Documents/Stats violation_2016_ENG.pdf.

Zimnenko, B.L. (2010). Mezhdunarodnoe pravo i pravovaia sistema Rossiiskoi Federatsii: Kurs lektsii [International Law and the legal system of the Russian Federation: The course of lectures]. Moscow, Statut, RAP, 416 p.

\section{Баланс интересов при защите прав детей: правовые позиции ЕСПЧ \\ и национальных судов}

К.В. Пылина

Сибирский федеральный университет Россия, 660041, Красноярск, пр. Свободныий, 79

\footnotetext{
Автор утверждает, что дети признаются самостоятельными субъектами, требуютими особого внимания и защитьы. Их права и интересы гарантируются как национальным, так и международным законодательством. Вмешательство органов власти в частную сфе- 
ру семейных отношений должно преследовать легитимную иель, средства вмешательства должны быть пропоричиональны этой иели. Автор рекомендует при решении споров, в которые вовлечены дети, осуществлять поиск справедливого баланса интересов, который носит многовекторный характер. Баланс предполагает учет интересов всех участников семейных правоотношений. Интересы детей являются самостоятельными и не зависят от интересов их родителей. В некоторых случаях интересы детей даже могут превалировать над интересами родителей. Применение правовых позиций Европейского суда, который во многих делах предлагает варианть баланса интересов, позволит снизить количество нарушений и обеспечить соблюдение прав детей.

Ключевые слова: баланс интересов, интересы детей, Европейская конвенция, Европейский суд по правам человека, семейные отношения, вмешательство государства.

Научная специильность: 12.00 .00 - юридические науки. 